\title{
Director's Liability For Losses in The Management of PT Merpati Nusantara Airlines as one of the State Owned Companies
}

\author{
Eny Suastuti \\ Faculty of Law \\ Universitas Trunojoyo Madura \\ Madura, Indonesia \\ enysuastuti@yahoo.co.id
}

\begin{abstract}
This paper is about the state's capital equity in establishing State-owned Company (PT Merpati SOE). Under private law regime, PT Merpati SOE, is anequity thatis a state asset allocated separately from the State Budget. Consequently, it is no longer a state asset; rather, it turns into a part of company assets. There is a case of a lease agreement of 2 (two) units of Boeing 737-400 and Boeing 737-500 between PT Merpati Nusantara Airlines with companies of Thirdstone Aircraft Leasing Group (TALG)the United States cannot be prosecuted under Articles 2 and3 of Act No. 31 of 1999 Jo Act No. 20 of 2001 on Eradication of Corrupt Practices Law. From this paper, three things are revealed. First, the state's capital equity, which has been allocated separately from state assets in establishing the PT Merpati SOE which is not a state asset; rather, it is thecompany's asset. Second, in the case of mismanagement which leads to company loss, the Directors of PT Merpati SOE may not be charged for committing corrupt practice as prescribed in Articles 2 and 3 of Corrupt Practices Eradication Law. Third, misperception has been made by judicial practices since the courts consider loss in particular transaction made by Directors of PT Merpati SOE as a loss of state finance whose implication is applied inArticles $\mathbf{2}$ and 3 of Corrupt Practices Eradication Law.
\end{abstract}

Keywords - corrupt practice, loss, state's capital equity, state finance (PT Merpati SOE)

\section{INTRODUCTION}

One of the characteristics of an enterprise is the asset separation of the legal entities of private wealth of its shareholders. The form of SOE is identical to the Limited Liability Company which is fully subject to the provisions of Act No. 40 of 2007 in the Company.The status of state as the shareholder of SOEs together with other shareholders, is subject to the provisions of the statutes and regulations regarding Limited Liability Company.

The existing financial status in SOE is always associated with the concept of state property is which is not apart from the listed terms of state finances on Act No. 17 of 2003 regarding State Finance and General Elucidation of Act No. 31 of 1999Jo Act No. 20 of 2001 on Eradication of Corrupt Practices. The lack of clarity regarding the position of the state in the state capital (SOE) has made the directors be responsible for the damages in the state (SOE) by using Eradication of Corrupt
Practices Act. Whereas, capital participation at the time of the establishment of state-owned enterprises (SOE) in the form of shares is an opt-in, meaning that the participation of countries taking part in a legal entity that is realized through stock agencies[1]. Therefore, legally it can be explained that the capital participation of the state in a state-owned enterprises (SOE) is a state property apart from the state's asset. Once the state puts its wealth, therefore, by law the asset belongs to SOEs.

Some provisions of the legislation has set about separation of assets of legal entities as written in Article 1 paragraph (2) of Act No. 19 of 2003 on State-Owned Enterprises (SOEs) which states that a Limited Company is a state whose capital is divided by shares, of which less than $51 \%$ owned by countries for profit making . Furthermore, Article 11 of Law on SOE states that SOEs are subject to all provisions and principles that apply to a limited liability company as stipulated in Act No. 40 of 2007.

Furthermore, Article 66 of Act No. 19 of 2003 imposes a public service and particular task onSOEs to carry out public service.This task will nottransform SOEs into a public legal entity. Yet, it remains the same as SOEs with its original characteristics which are fully controlled by private law. In relation to that, Peter Mahmud Marzuki points out that the state is a political entity which is in charge of providing welfare of its people in order to facilitate the society.The state may be involvedin business only for public service. However, the state may not run business since it is a private area and controlled by private law regime.

Therefore, the case at PT Merpati Nusantara Airlines (PT MNA) in case Number: 36/Pid.B/TPK/2012/ PN.JKT.PST, the defendant D.P Hotasi Nababan. The Public Prosecutor charged the defendant by applying Article 2 and Article 3 of thePTPK Law. The failure of Third stone Aircraft Leasing Group (TALG) in shipping two (2) aircrafts : Boeing 737-400 and 737-500 Boeing as promised to PT MNA and did not refund the security deposit of US $\$ 1,000,000$ paid by PTMNA cannot be charged to PT MNA's Director because the defendant as Director of PT MNA has fully complied in making a lease agreement for two (2) aircrafts and placing a 
security deposit of US \$1 million to 2 (two) aircrafts to TALG with care, good will for the sake of companies under thecircumstances faced by PT MNA. PT Merpati Nusantara Airlines stated that the mishap is a business risk. However, the Attorney claims there is the loss suffered by the state in the procurement of the aircraft lease.Thus, business risk is viewed as a loss in the financial management in that company.

The Public Prosecutor in their indictment accuses the defendant of making personal, other individual or corporate profits in making aircraft lease agreement. The indictment has beenproven. However, PT MNA finds the corruption allegation against the Board of Directors of PT Merpati Nusantara Airlines (SOE) is contrary to the principles of Business Judgment Rule. The principles of Business Judgment Rule states the director's decision was valid and binding and shall not be ignored by the shareholders and the judge unless the directors violate the duty of loyalty. This paper isprepared topinpoint one of the characteristics of an entity;the separation of the assets of legal entities of private wealth of shareholders and the law systems. In addition, the MNA case is analyzed as a reflection of one of the characteristics of an entity that is a separate legal entity from the wealth of shareholders.

\section{RESEARCH METHODS}

The type of this article is a legal research, that used statute approach, case approach and conceptual approach. This research will analyzing misperceptioan has been made by judicial practices since the courts consider loss in certain transaction made by Directors of State-owned Company to be loss of state finance whose implication is applicability of Articles 2 and 3 Corrupt Practices Eradication Law.

\section{RESULTS AND DISCUSSION}

\section{A. Characteristics of State-Owned Enterprises (Persero)}

Theparticipation of state capital in SOEs is generated from the state budget.Then it is separated to serve as the founding capital for SOEswhich is not the state assets. Yet, the legal status has changed to wealth owned bySOEs. The Government official legal position as a shareholder or a commissioner of SOEs is equal or equivalent to the legal position of the other private shareholders. The public immunity asthe government official is no longer valid, fully complies to private law despite state-owned shares provision.

The Director of Soes is an official in civil law (private) and is not a public official.The subject of authority abuse of in Article 3 of Act.Law of Eradication on Corrupt Practices is not appropriately applied to the Board of Directors of SOEs since the authority of the Board of Directors of SOE is categorized as the authority of private subjects. Subjects of the authority abuse in Law of Eradication Corrupt Practices are public officials or civil servants. Thus, the Director of PT Merpati Nusantara Airline (PT MNA) is not a public official nor a civil servant because he has no public authority. His authority isthe private authority.Therefore, the losses incurred in PT MNA is not the state financial loss as stipulated in Articles 2 and 3 of Corrupt Practices Eradication Law.

As a matter of facts, some verdicts state that the state capital participation in SOEs (Persero) categorized as state finances by relying on the provisions of Article 2 (g) of Act No. 17 of 2003 which states that State Finance, includes the state/ region's treasure ismanaged by the Government or other parties in the form of money, assets, bills etc., including the state/ region's treasure that is separated in SOEs. This is a fraud in the Indonesian judicial practice, as well as the allegation of Director of Merpati Nusantara Airline, (PT MNA) Hotasi D.P Nababan as a defendant by the Public Prosecutor indicted, the primary charge by applying Articles 2 (1)and Jo. 18 and subsidiary charges to by applying Articles 3 and Jo. 18 of Corrupt Practices Eradication Law and Jo. Article 55 paragraph (1) 1st Criminal Code is improper.

According to Act No. 19 of 2003 on State-Owned Enterprises in Article 1 paragraph (2) and 11Act No. 40 of 2007 which state that losses incurred in the management of the company require the Director to be responsible for all policies he made in the share holders made in the Shareholders meeting. In the meeting, the shareholders may accept or decline the policies and report of the Director. Rudhi Prasetya points out that in the case in which the Board of Directors have accepted the Director's policies. Thus, he is released from his responsibilities as the Director. In the Law of Limited Company it is called "volledigeaquit et de charge" or it is said that the Director has obtained "release and charge".

A Limited Company or so called as SOE as a legal entity has 3 organs : the Shareholder meeting, Commisioner and Board of Directors. The shareholder meeting is the top level management as stipulated in Article 1 (13) Law No.19 of 2003. The duties and authority of the share holders are listed in details in the provisions of the Company Limited Budgets. Commissioner is the organ in charge of supervising the directors in running the company as stated in Article 31 of Law SOE which elaborates that the commissioner is in charge of supervising Directors in running the SOEs and advise the Board of Directors. Furthermore, the third organ is the Board of Directors. The responsibilities of the Board of Directors as the Board of SOEs to represent the interests and objectives of SOEs PT both inside and outside the court [2] supported by Article 5 (3) of the SOE Act which states that in carrying out the duties the directors must meet SOE statutes and regulations as well as implement the principles of professionalism, efficiency, transparency, independence, accountability, responsibility and fairness.

\section{B. The Responsibility of The Board of Directors For Losses Incurred in SOEs And Corruption}

SOEs established by the state in civil law perspective complies to private law. It is very important to build the 
business environmental in Indonesia may has impact nationally, regionally and internationally, Indonesia has been an outlier within the Southeast Asia region, with lower inflows of foreign investment (FDI) compare to other countries, especially in manufacturing sector,and with lower inflows than could be expected from its size and other country characteristics [3].

In relation to the responsibility if a loss is incurred in the SOEs, based on the wealth in state capital participation in which the state wealth is separated from state assets budget Revenue Expenditure (APBN) to serve as the state capital participation. With the above concept, the government as shareholder for losses incurred in SOEs is limited to the paidup capital. It means that the government as a shareholder have the same rights and obligations as other shareholders.

In other words, the government cannot represent the state as a legal public entity sinceit has lost the public immunity upon signing up the state capital participation. The state assets, later, has turned into capital investments. Thus, the Director has a limited responsibility, in case of any frauds or mismanagement which occur in the company. Consequently, the allegation charged on the Director is improper

In the PT Merpati Nusantara Airlines case in which the Director is charged for misconduct in making the aircraft lease agreement between PT Merpati Nusantara Airlines and TALG. According to the Prosecutor, the element of Article3 of Corrupt Practices Eradication Law namely "benefit themselves or other persons or companies has been proven.The underlying reason for the above statement is first Security deposits have not yet been paid to TALG because itfails to show documents of the purchase (purchase agreement) between TALG with East Dover under the terms of LASOT. Secondly, the accused knew the security deposit paid will be used TALG as the down payment for the purchase of aircraft and not as a collateral. Thirdly, the security deposit is not refundable so that PT MNA suffered losses of US \$ 1 million.

In consideration of the verdict of No.36/Pid.B/TPK/2012/PN.JKT.PST, the judge stated that the business transactions are always expected is to be profitable as well TALG expects to benefit from the rental business with PT MNA. As a business operator, the management of PT MNA is already aware ofand know that the transaction of aircraft lease with TALG will obtain profit. The amount of profit depends on the business calculations performed by TALG. PT MNA has already calculated the income earned from the aircraft rental costs paid TALG. Furthermore, the judge, in his consideration, stated that the intention (means rea) of the accused from the beginning is to rent the aircraft to increase its fleet to improve the financial performance of PT MNA. Payment of security deposits is a consequence of the signatories LASOT conducted by PT MNA. Furthermore, the judges on refundable security deposit clause in LASOT showed no intention or purpose of PT MNA to share profits to TALG for the security deposit of US \$1,000,000.00.

The principle of civil law states that state assets are separated from the state budget is not a government asset because of the capital supplied by the government and wealth comes from the separated state. A SOE is a limited liability company and capital arrangement which comply to the principles of corporate law. This is confirmed in Law No. 40 of 2007 regarding Limited Liability Company stated, the authorized capital stock is comprised of all shares in the nominal value of the company.

The case of a lease agreement on aircrafts between PT Merpati Nusantara Airlines with the United States company(TALG) is a business risk due to the unhealthy financial condition of PT MNA. Thus, it is not trusted by the lessor, so to get the aircraft lessor asked PT MNA to place a security deposit and must be paid in cash. This is a very difficult choice for the PT MNA and must be decided. Every business decision contains risks. If no risk is expected in business, then do no business. As a result, the company will not operate. For the company management itis also essential to improve enterprise and business decision-making must be disposed of carefully and solely for the sake of the company. If a loss is incurred, then it is taken as a business risk.

Parties to the Public Prosecution considers any state assets in the company PT Merpati is the state's finances. Business risk is seen as a loss in the financial management of the state of the company. Therefore, the prosecution considers the assets at PT Merpati Nusantara Airlaines (SOE) isa state asset/ financial state and its loss is a loss to the state. As a result, this raises legal issues in assessing the Director's responsibility. PT Merpati Nusantara Airlines (SOEs) is identical to any private enterprises. The shares owned by the state in PT MA remains the shares of PT MNA. Thus, the director's responsibility of PT MNA is very important.

According to Indriyanto Seno Adji associated with the policy of directors in reaching a decision inthe company management which results in mismanagement or loss. It is included in the area of the State Administration as a policy of the state operators (Overheidsbeleid). Why?The directors of SOEs is the subject of the notion of civil servants according to the Law of Eradication of Corrupt Practices.Whereas, theapproval process in the management of PT Persero is the area of civil law as "privaatrechttelijkheid"[4].

In relation to the duties of directors of the provision of Article 95 paragraph (5) of ActNo. 40 of 2007 states in managing the company, the directors have a particular freedom entrusted to manage the company, and they cannot be prosecuted for any policies they make.

The directors' actions can be prosecuted and constituted as a criminal offense according to Erman Radjagukguk due to:

a. organizing extra bookkeeping accounting; 
b. recording expenses that are not real (fictional)

c. using falsified documents

d. deliberately damaging book-keeping documents.

Furthermore, Erman Radjagukguk states, in the company legal doctrine known as "business judgment rule" states that company directors are not liable for damages arising out of an act of decision-making, if such action is based on goodwill and care. Directors receive legal protection without the need to obtain justification of shareholders or the court of his decision in the context of the management of the company [5]. Elements of prudential measure of compliance in the use of financial companies and ask for approval of the AGM. When linked with the case of PT MNA has not refunded the security deposit by TALG since there is no loss incurred in the state finance, because TALG sentenced to pay for damages asa breach of contract.

Their doctrine of "business judgment" to protect the directors to be more willing to take risks because in every business decision always contains risk a. The most important is how to improve the company. If too much care is takenthe business will not run.This is the justification for the business risk of the shareholders or the court of its decision in the context of the management of the company. This business judgement shows that the court can not make a better decision in business rather than the directors of the company. The court has no business skills and they notice the case after the hearing of the case at the court.

In this regard, Ridwan Khairandy states, losses in a business transaction specified not by itself result in losses for the company because it is based on Article 66 of Law Company Limited is mentioned at least five (5) months after the book-keeping, and the company closed. Later the directors prepare an annual report to be submitted to the AGM which includes the calculation of year-end balance sheet and the past of the new book, the calculation of netincome [8].

\section{Analysis of The Courts Verdict in The Case of PT Merpati Nusantara Airlines (SOES)}

The case in PT Merpati Nusantara Airlines (PT MNA) in case Number: The Prosecutor accused the defendant D.P Hotasi Nababanin 36/Pid.B/TPK/2012/PN.JKT.PST. The Prosecution indicted by using Articles 2 and 3 of Corrupt Practices Eradication Law . Lease agreement Boeing737-400 and Boeing 737-500 aircraft on December 18, 2006 between PT Merpati Nusantara Airline, represented Tony Sudjiarto as the General Manager of Procurement based on a power of attorney of the defendant Hotasi DP Nababan signed a deal of the Summary of Term Lease Agreement (LASOT) Jakarta with Jon Cooper as $\mathrm{CO}$ of Thirdstone Aircraft Leasing Group (TALG). Afterwards, on December 19, 2006 TALG, represented by Alan Mesnersigned the Summary of terms for the sale of one (1) Boeing 737-400 Aircraft and Summary of terms for the sale of one (1) Boeing 737-500 Aircraf with the
East Dover Limited.In accordance with the Term Summary TALG parties must pay a deposit of US \$500,000 (five hundred thousand US dollars) for each aircraft. On December 20, 2006 as a follow up of LASOT, the accused and Captain Harry Pardjaman of PT MNA signed the Lease Agreement for the Boeing 737-500 and the TALG represented by Alan Mesner as CO. The signing is conducted through the scanner and email, and for the Boeing 737-400 aircraft lease agreement has yet been made.

The failureof Third stone Aircraft Leasing Group (TALG) to ship two (2) aircraft Boeing 737-400 and 737-500 Boeing promised to PT MNA and did not return the security deposit of U \$ 1000.000 who have paid PTMNA cannot be charged to the accused because the defendant as the Director of PT MNA in making a lease agreement for two (2) aircraft and fulfill an agreement to place a security deposit of US \$ 1 million to 2 (two) air to TALG done with care, and goodwillfor the sake of-of the companies under the specific circumstances faced by PT MNA.

Therefore, the case of PT Merpati Nusantara Airline is a civil case, and the law applied is private law due to its matter related to the lease agreement which complies to private law.Therefore it cannot be shifted to criminal law. Basically, in an agreement of all the parties involved have the goodwill to fulfill their obligations under the agreement that has been agreed and signed by both parties. If one of the parties fail to perform their obligations, the failure is considered as a breach to the agreement.

Thus, the security deposit placement is a common practice performed by companies in terms of business in lease and a security guarantee for the lessor if the lessee fails to pay rent. Yet, the Prosecutor considers the security deposit placement is too early to be paid because TALG is unable to show documents of the purchase (purchase agreement) between TALG East Dover in accordance with the requirements in LASOT.

In the General Meeting of Shareholders (AGM) PT MNA dated October 11, 2006 has set the Work Plan Budget (CBP) associated with aircraft procurement policy, describes the fleet that are operated and aircraft procurement plan. Therefore, CBP serves as a reference for the directors to run the company's operations during the year. However, in practice the Board of Directors must also pay attention to the situation and the growing conditions and faced when a business decision to be made. The procurement B737 series 400 and 500 could have not explicitly been planned or budgeted in CBP of PT MNA in 2006.However, if the board of directors considers the decision taken is very profitable for the company. This action should not be included in the category of unlawful acts provided that the decision-making is made with care, goodwill,andwith no conflict of interest and solely for the sake of the company. 
Parameter or benchmark to determine whether a loss is not caused by business decisions (business judgment) is the first to have information about the matter to be decided upon and believe that the information is correct, the second does not have an interest in the decision and decided to goodwill, the third, own a rational basis to believe that the decision taken is the best.

In a dynamic business world, speed and accuracy in taking the decision is often the key to success in competition with the competitors. Risks related to the assessment of a business between one company with another company is not the same in the decision making. This means that a company's airline is large and has a good reputation with the company airline which always makesa loss and is often late to fulfill their obligations, and this condition is experienced PT MNA, Therefore whatever decision they make will result in business risks and loss. The risk of a business decision is always there and inevitable.The possible action is to minimize the risk in order not to cause a great loss for the company. The failure of TALG in shipping aircraft on the promised date and have been given an extension of time for 30 (thirty) days still cannot meet their obligations to PT MNA should be seen as a risk in business, and also PT MNA as the lessee has right to terminate the agreement and TALG is obliged to return Security Deposit including the interest.

Andi Hamzah and Erman Radjaguguk declared losses suffered by PT (SOEs) on a particular transaction does not mean losses for state-owned enterprises, as there may be transactions that are profitable. Thus, it isinappropriate if the loss on a transaction of a specific business automatically be the loss of the company, let alone it is considered as the state losses. There is a fault in the judicial practice in which the directors of state-owned enterprises (SOEs) are charged with corruption practice for a particular transaction which incurs losses for the company.

In relation to this case Rudhi Prasetya states if the policies in running SOEs and the responsibilities of the executive directors have been accepted by the GMS, then legally directors exempt from responsibility for losses incurred in the management of state-owned enterprises (SOEs), and must be considered to have completed the responsibility of the Board of Directors. In the law of SOEs, it is defined as the Directors of the company have obtained the "volledigeaquit et de charge". In English, they have obtained the "release and the charge". The word "aquit" means no longer recur and has been given "release" (liberation). Exemption from the "de charge" (charges). Application of the principle of "volledigeaquit et de charge" is stipulated in the consideration of the Supreme Court ruling No. 1912.K/Pid.Sus/2008, dated June 25, 2009 basically stated defendant had been released from responsibility in the GMS (PTPN XI).

In their consideration for the case Number: 36/Pid.B/TPK/2012/PN.JKT.PST. with DP Nababan Hotasi , the defendant, the judges state that the reference element "with the intention of enriching himself, others or a corporation 'is their intention, knowledge and awareness of the consequences that would arise from an act. The result is to make a profit for themselves, another person or a corporation. Furthermore, the Assembly of judges assume that in business transactions are always expected is a profit, as well TALG expect to benefit from the best rental businesses to PT MNA. As a business management PT MNA has already been aware and learned that the transaction lease aircraft with TALG will benefit TALG as well.

In addition, the judge assembly assume that the defendant, from the beginning, did not have the intention to benefit himself in the procurement agreement lease the aircraft. The aim of the lease agreement is to increase its fleet in order to improve the financial performance of PT MNA. Payment of security deposits is a consequence of the signing the lease agreement, and it is definitely not to give profit against TALG. The defendant did not know that the payment of security deposit would be used to pay for the down payment to the East Dover Ltd by TALG . Besides, PT MNA keeps asking for the return of the security deposit to TALG as well as to punish them. Therefore, according to the judges assume thatthe element of intentionally enriching themselves, another person or corporation is not proven by law.

Furthermore, the panel of judges declare the defendant is not legally provenand convincingly guilty of committing a crime in both the primary charges and subsidiary charges

\section{CONCLUSION}

1. Concepts of state assets set aside in the state capital participation in SOEs is a state asset separated from the State Budget (APBN). Yet the management remains based on the principles of civil law, so that instead of being the state wealth but it is the wealth of the company.

2. The judicial practice in Indonesia the concept of state assets/ state finance set aside remains a part of state finance, so that law enforcement officers can still prosecute and convict corruption against the SOE (PT MNA) as stated in the Act of Eradication Corrupt Practices, State Finance Law, Law on CPC.

3. The judges had the right verdict in the case of 36/Pid.B/TPK/2012/PN.JKT.PST. defendant Hotasi DP Nababan by declaring the defendant was not legally proven and convincingly guilty of committing a crime, both in the primary charges and subsidiary charges.

4. According to the judge Hotasi DP Nababan defendant in conducting lease Boeing 737-400 and Boeing 737-500 and making a payment security deposit of US \$1.000.000.00 (one million dollars) has been carried out transparently, carefully, heartedly, without conflict of interest and in line with good corporate governance (GCG).

5. There is no intention of the defendant to seek for the procurement of the lease agreement of the plane, in order to increase its fleet in order to improve the financial 
performance of PT MNA. In addition, payment of a security deposit of US \$1000.000.00 is a consequence of the signing of the lease agreement (LASOT), and not to give profit against TAL. Furthermore, the defendant also did not know the security deposit payment of US \$ 1000.000 .00 will be used for a down payment of plane by TALG to East Dover.

\section{ACKNOWLEDGMENT}

The research was done with fund support from Faculty of Law, Universitas Trunojoyo Madura.

\section{REFERENCES}

[1] P. Rudy, the Position of Independent Company Limited with elaboration according to Act No 1 of 1995. Bandung: Citra Aditya Bakti, 1995.

[2] I. Government, State Owned Company. Indonesia, 2003, p. 9.

[3] D. Oktiani, "The Impact of Corruption on Domestic and Foreign Investment in Indonesia," Proc. Int. Conf. Ethics Gov. (ICONEG 2016), 2017.

[4] I. S. Adji, Crime in Banking, Use Law Combating Criminal Acts in Banking. Jakarta: CFISEL, 2007.

[5] E. Radjagukguk, Silent Singing Towards Indonesia: the Law and Democratic State. Jakarta: Fakultas Hukum Universitas Indonesia, 2006. 